\title{
Impact of urbanization processes on availability of ecosystem services in National Capital Region of Delhi (1992-2010)
}

\author{
Chandra Prakash Morya ${ }^{1} \cdot$ Milap Punia $^{2}$
}

Received: 29 July 2020 / Accepted: 6 August 2021 / Published online: 16 August 2021

(c) The Author(s), under exclusive licence to Springer Nature B.V. 2021

\begin{abstract}
The Southern and Eastern National Capital Region of Delhi is experiencing diversified and expanding urbanization as in million-plus cities of the area the urban sprawl activities are more frequent than the urban densification activities. The progressing sprawl of residential and construction sites is transforming the regional ecosystems and hampering the generation of ecosystem services of fundamental importance, i.e. the benefits and services that we get directly or indirectly from the ecosystem functioning. The Costanza et al., (2014) approach shows that the ecosystem services value has decreased at US\$ $56 \mathrm{ha}^{-1}$ year $^{-1}$ $\left(0.09 \%\right.$ per year) and absolute and cumulative losses are estimated US\$ $285.4 \mathrm{ha}^{-1} \mathrm{year}^{-1}$ and US\$ $502.8 \mathrm{ha}^{-1}$ year $^{-1}$, respectively. The ecosystem service values assessment shows that the ecosystem services like climate regulation and recreation have increased but food production, genetic resources, water supply, soil formation, raw materials and waste treatment have decreased over the time. The use of alternative ecosystem value coefficient shows that the estimated value of the ecosystem service value changed from a low of $0.005 \%$ for $1 \%$ change in the value of the forest coefficient, to a high of $0.749 \%$ for a $1 \%$ change in the value of the agricultural land coefficient. For each land use/land cover category, the sensitivity analysis reflects the inelasticity or robustness of the estimated ecosystem value with respect to the value coefficient. Overall, prioritizing the conservation and enrichment of natural and man-made ecosystems of critical value will lead to sustainable development of urban ecosystems.
\end{abstract}

Keywords Ecosystem services · Ecosystem function · Recreation · Valuation · Land use · Delhi

Chandra Prakash Morya

chandra.morya@gmail.com

Milap Punia

milap.jnu@gmail.com

1 Department of Geography, University of Rajasthan, Jaipur 302004, India

2 Centre for the Study of Regional Development, School of Social Sciences, Jawaharlal Nehru University, New Delhi 110067, India 


\section{Introduction}

Human impacts on the global environment are operating at unprecedented magnitudes, rates and a wide range of spatial scales and overlap in many areas (Turner et al., 1994). The natural ecosystems are being converted into human dominated ecosystems (Daily, 1997). Recently, urbanization-induced land use/land cover changes are the key drivers of the Earth's ecosystem function (Lambin et al., 2001). In urbanizing regions, urban sprawl leads to the shift from a natural steady state of abundant and well-connected natural land cover to a second steady state of greatly reduced and highly fragmented natural land cover (Alberti \& Marzluff, 2004). More than two-thirds of the area of the world's 14 major terrestrial biomes and more than half of the area of 4 other biomes had been converted by 1990, primarily to agriculture (MEA, 2005). In the last 50 years, the growing demand for food, fibre, fuel and water has changed the ecosystems more rapidly and extensively than in any comparable period of time in human history (MEA, 2005). The population, technology and lifestyle are indirect drivers that lead changes in the biodiversity and eventually result in changes to ecosystems and the services they provide, thus affecting human well-being (MEA, 2005). Globally, built-up areas cover almost $0.5 \%$ of planet's area but they exert larger ecological footprints and powerful, complex and indirect effects on ecosystems (Alberti et al., 2003; Angel et al., 2011). Not only the climate change and land use changes but the increasing pollutant load is also altering the structure, function and dynamics of Earth's terrestrial and aquatic ecosystems (Grimm et al., 2008). The degradation of ecosystems and associated loss of biodiversity is expected to negatively impact ecosystem functioning and resilience (TEEB, 2011). The continuous degradation of ecosystems will further disrupt the flow of ecosystem services for present and future generations (TEEB, 2011; de Groot et al., 2012).

The cities transform critical habitats of global value and impact the biodiversity maintenance and functional ecosystems through the sprawl and intervention to the natural ecosystems within and outside the city (Müller et al., 2013). Ecosystem goods and services represent the benefits human populations derive, directly or indirectly, from ecosystem functions and are of fundamental importance to human well-being, for health, livelihoods and survival (Daily, 1997; Costanza et al., 1997, MEA, 2005; de Groot et al., 2012). There is strong need for ecologically socially and economically viable investments to restore and protect the ecosystems within and outside the city (Elmqvist et al., 2015). But some of the ecosystem functions, processes and services can negatively impact on human well-being, termed as ecosystem disservices (Shackleton et al., 2016). There are evidences of ecosystem disservices like disease emergence (SARS, Ebola, COVID-19) (Everarda et al., 2020), water quality degradation, the alteration of marine ecosystems (coral bleaching), the collapse of fisheries (McClanahan, 2009) and shifts in regional climate (van der Geest et al., 2019). There is need to understand what they are, what helps create them, how they link to activities on the site, who benefits and the spatial relationship between service provision and the beneficiary, what is being lost and the value of what is being lost (TEEB, 2011). In the modified ecosystem services cascade framework (Fig. 1), it is depicted that change at one point in the system triggers further changes because of the reinforcing loop of ecosystem services flows, whereby benefits derived from particular land uses lead to more changes by local people to those land uses to ensure supply of more services (HainesYoung and Potschin, 2010; Fedele et al., 2018).

The ultimate benefits of all the services seem the welfare of human beings. But are these services and benefits are equal everywhere? If not why functioning or processes of 
Fig. 1 The modified ecosystem services cascade framework (Haines-Young and Potschin, 2010; Fedele et al., 2018)

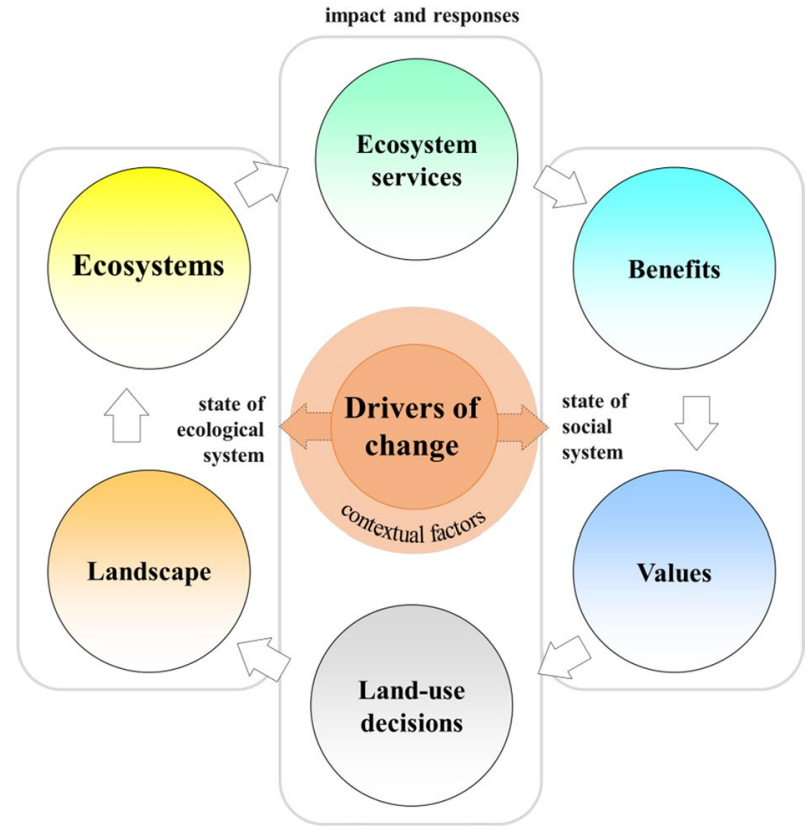

ecosystem vary from place to place and can it be changed? The intensified land use for agricultural production has helped in hunger and poverty reduction globally but the harmful effects of degraded ecosystem services are being borne disproportionately by the poor (MEA, 2005). Biodiversity is important for all but essential for the rural poor who often rely directly on local ecosystem services and biodiversity for their food, shelter, income, fuel, health, quality of life and community (TEEB, 2011). Thus, the benefits and harmful effects are affecting disproportionately and causing inequalities, disparities and social conflicts. The benefits of ecosystems can be categorized as social, cultural and economic. The biophysical quantification methods (Balvanera et al., 2005), socio-cultural methods (Sodhi et al., 2010) and economic valuation methods (Castro et al., 2011; Martín-López et al., 2012) are used to support environmental policy decisions. The monetary expression of the benefits of the ecosystem services can raise awareness to protect and enhance ecosystems globally (de Groot et al., 2010, 2012).

The valuation of ecosystem services can improve understanding of problems and tradeoffs, be used directly to make decisions, illustrate the distribution of benefits and thus facilitate cost-sharing for management initiatives and spur the creation of innovative institutional and market instruments that promote sustainable ecosystem management (Chee, 2004; Daily, 1997). In resource management decisions, the marketed benefits of ecosystem services are on higher priority and non-marketed benefits are often lost or overlooked, though these non-marketed benefits are often high and sometimes more valuable than the marketed ones (MEA, 2005). The monetary valuation helps to make decisions about allocating resources between competing uses (de Groot et al., 2012). In this study, proxy valuation coefficients (Costanza et. al., 2014) have been used for monetary valuation of ecosystem services which provide not accurate but quite trustworthy estimations of total ecosystem services value to policy implementation and decision-making at multiple scales and to raise consciousness to protect ecosystems. The physical assessment of ecosystem 
services is not sufficient to mitigate the increasing pressure of urbanization over resources. In the resource management decisions, the incorporation of non-marketed values of ecosystem services is essential for the welfare of human beings. There is strong need for comprehensive and quantitative understanding of the ecological benefits and their values with a strong rationale for decision-making and implementation. In this study, we have used have used WB-ESA datasets because it is in a more synoptic and consistent manner with an overall thematic accuracy of more than $80 \%$. Using the WB-ESA datasets, an attempt has been made to analyse pros and cons of urban land management and urban sprawl scenarios at district level during 1992-2010. We have also attempted for relative monetary valuation, ecosystem function and sensitivity analysis of ecosystem services during 1992-2010 in Southern and Eastern National Capital Region of Delhi.

\section{Material and methods}

In the study, an attempt has been done to highlight the status of urban land management and urban sprawl practices and land use/land cover (LULC) changes during 1992-2010 in Southern and Eastern National Capital Region of Delhi. We have followed Costanza et al., (2014) approach to identify and for monetary valuation of 17 ecosystem services for 16 major biomes based on the functioning of the ecosystems in the study area. We have tried to find out the effectiveness of using generalized ecosystem services value coefficient (suggested by Costanza et al., 2014) to estimate the annual economic value (marketed and nonmarketed) of ecosystem services.

\subsection{Study area}

The National Capital Region Delhi of India is the largest urban agglomeration encompassing around 55,083 sq. km area (NCRPB, 2021). The National Capital Region (NCR) of Delhi in India was constituted under the NCRPB Act 1985 with the key rationale to promote balanced and harmonized development of the Region and to avoid any haphazard development (NCRPB, 2021). It includes National Capital Territory of Delhi (1483 sq. $\mathrm{km}$.) and thirteen districts of State of Haryana (25,327 sq. km), seven districts of State of Uttar Pradesh (14,826 sq. km.) and two districts of State of Rajasthan (13,447 sq. km.). The study area, i.e. Eastern and Southern National Capital Region of Delhi, is predominantly agrarian and densely populated region, comprising 11,380 sq. km. area (Fig. 2). The Eastern and Southern National Capital Region of Delhi comprises NCT Delhi; Baghpat, Sardhana, Meerut, Ghaziabad, Hapur, Dadri, Sikandarabad and Khurja districts of NCR sub-region of Uttar Pradesh state and Gurgaon, Faridabad, Pataudi, Nuh, Hathin and Palwal districts of NCR sub-region of Haryana state (Fig. 2). There are 4 million plus cities in the Southern and Eastern NCR of Delhi, i.e. NCT Delhi, Ghaziabad, Faridabad and Meerut and in upcoming decade, Gurgaon is expected to emerge as new million-plus city (Census of India, 2011). Further in the study the Southern and Eastern National Capital Region Delhi will be addressed as NCR Delhi. Geomorphologically the study area is moderately sloping in which the alluvial plain occupies a major portion of it and is formed by the Yamuna and the Ganga rivers. The paleo-channels are confined in between the Ganga and the Yamuna courses in the Eastern and the central part of NCR. The Hindon River, a major tributary of the Yamuna River, rises from Southern slopes of the Shivalik in Saharanpur district of Uttar Pradesh and ultimately meets the Yamuna from the left downstream 


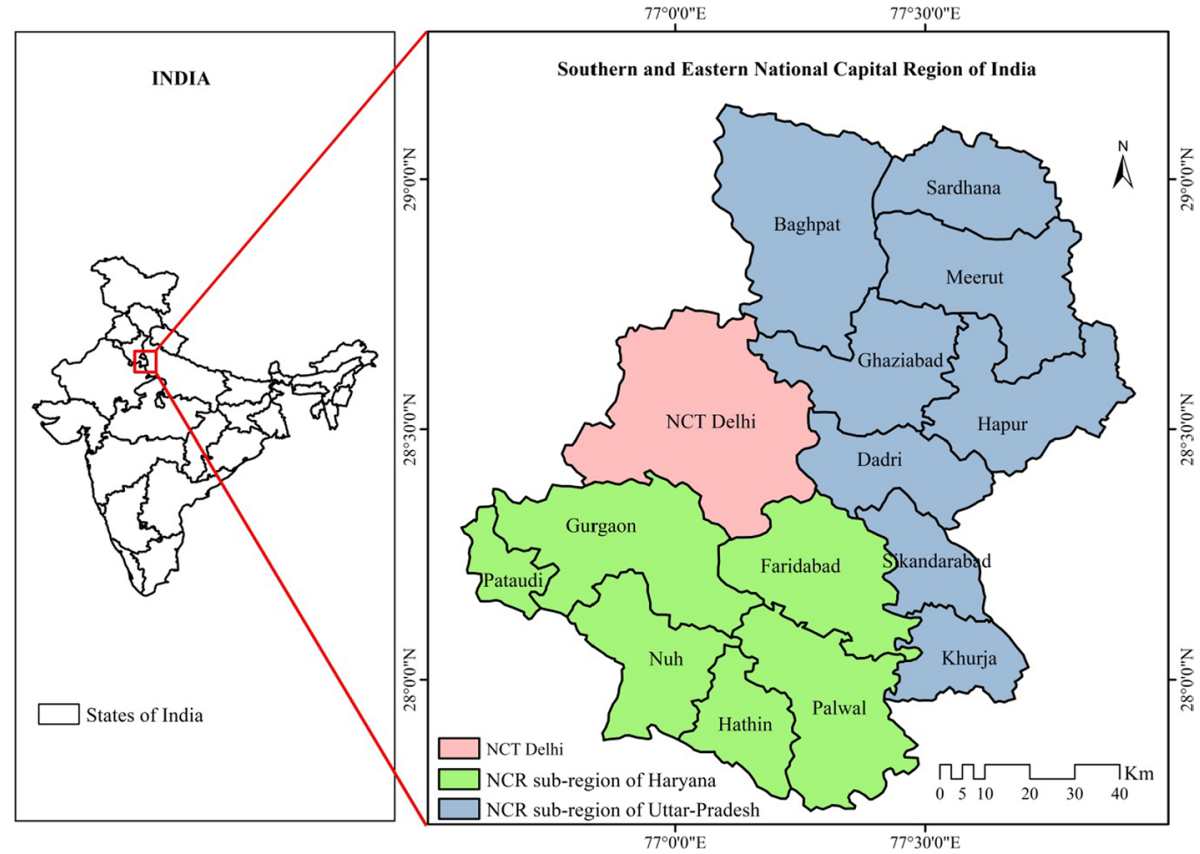

Fig. 2 Study area-Southern and Eastern National Capital Region (authors work)

of Okhla. The extension of Aravalli ridge is exposed as isolated residual and structural hills and pediments in adjacent areas of Gurgaon district, National Capital Territory (NCT) Delhi and Faridabad district. The other natural and man-made ecological features are Badkal Lake, Surajkund Lake, East Yamuna canal, upper Ganga Canal, Gurgaon Canal, Agra Canal and sanctuaries (NCRPB, 2021). Most of the study area is predominantly irrigated through well-developed canal network except Gurgaon district which is tube-well irrigated (NCRPB, 2021). According to the regional plan 2021, these natural areas are demarcated as highly sensitive areas to maintain the ecological balance in the region.

In India the urban areas are being treated as central to economic and industrial development and explicit developmental strategies are being followed (Nagendra et al., 2013). The study area is predominantly experiencing increase in urban fabric construction sites, industrial and commercial sites and transport corridors. Thus, the agricultural land is being continuously engulfed by the artificial conversions and developmental activities (GISAT, 2011). In recent decades, the inflow and investment of capital, better urban management practices, improved employment growth and economic opportunities have led to a high rate of population growth in the National capital region (NCR) of India (Morya \& Ram, 2019). Resultantly, the growth of population of NCR Delhi has contributed to increasing congestion and shortages of civic amenities (NCRPB, 2021). It has been felt that as Delhi urban agglomeration grows, its problems of land, housing, transportation and management of essential infrastructure like water supply and sewerage would become more acute (NCRPB, 2021). The improved transportation network in the NCR region, better housing and civic services and decentralization of employment opportunities have caused the growth of new urban centres in the periphery of NCT Delhi (Morya \& Ram, 2019). The urban population growth rate is declining in the core NCT Delhi, but it is increasing 
constantly in the peripheral towns in the NCR Delhi (Morya \& Ram, 2019). This increase in built-up and population density is expected to have impact on the natural environment, natural resources and open spaces within NCT Delhi as well as in surrounding areas also (CPCB, 2000; Morya \& Punia, 2017; Nagendra et al., 2014).

\subsection{Database}

The land use/land cover datasets with $>80 \%$ accuracy and thematically classified have been taken from the study conducted by ESA on "Historical Assessment of Spatial Growth of Built-Ups in Metropolitan Areas of Delhi and Mumbai in India and Dhaka in Bangladesh" in the framework of the "eoworld" initiative supported by the European Space Agency (ESA, 2011). The 'eoworld' initiative has used high-resolution imageries from Spot 2-5 archives and RapidEye satellite imageries to derive these datasets for three time periods, i.e. 1992, 2003 and 2010. The datasets are aimed to explain the spatial and temporal patterns, intensity, processes, impacts and inner dynamics of changes in land use/land cover. Originally, the data have been provided in 15 land use/land cover categories by 'GISAT' which has been reorganized into 10 land use/land cover categories, according to the standard classification scheme of land use/land cover adopted by European Space Agency (ESA). Technically standard nomenclature has been adopted for 10 land/use/land cover categories out of which 4 are urban related (Table 4). Table 1 provides details about the standard nomenclature for the urban land management and urban sprawl activities.

\subsection{Measurement of urban land management and urban sprawl}

The urban land management includes the processes of 'urban densification', 'urban infilling', 'internal conversions' and 'reduction of urban greenery' operating in the area in a particular duration (i.e. 1992-2003 or 2003-2010) (Table 1). The urban sprawl is the function of 'urban residential sprawl', 'sprawl of industrial, commercial and transport sites' and 'sprawl of construction sites' operating in the area in a particular duration (Table 1).

Urban land management can be expressed as follows:

Table 1 Urban land management and urban sprawl (Source: WB \& ESA, 2011, compiled by authors)

\begin{tabular}{|c|c|}
\hline Urban land management & Description \\
\hline Urban densification & Increase of urban fabric density \\
\hline Urban infilling & Conversion of construction sites into developed urban areas \\
\hline Internal conversions & Functional changes within already developed area \\
\hline Reduction of urban greenery & Reduction of urban greenery, through extension of artificial land \\
\hline Urban sprawl & Description \\
\hline Urban residential sprawl & $\begin{array}{l}\text { Land uptake by the residential buildings altogether with associated services } \\
\text { and urban infrastructure }\end{array}$ \\
\hline $\begin{array}{l}\text { Sprawl of industrial and com- } \\
\text { mercial sites and transport }\end{array}$ & $\begin{array}{l}\text { Extension of industrial and commercial areas and associated land at the } \\
\text { expense of non-urban land }\end{array}$ \\
\hline Sprawl of construction sites & $\begin{array}{l}\text { Spread of construction sites over former non-artificial land, mostly indicates } \\
\text { extension of urban land in the future }\end{array}$ \\
\hline
\end{tabular}




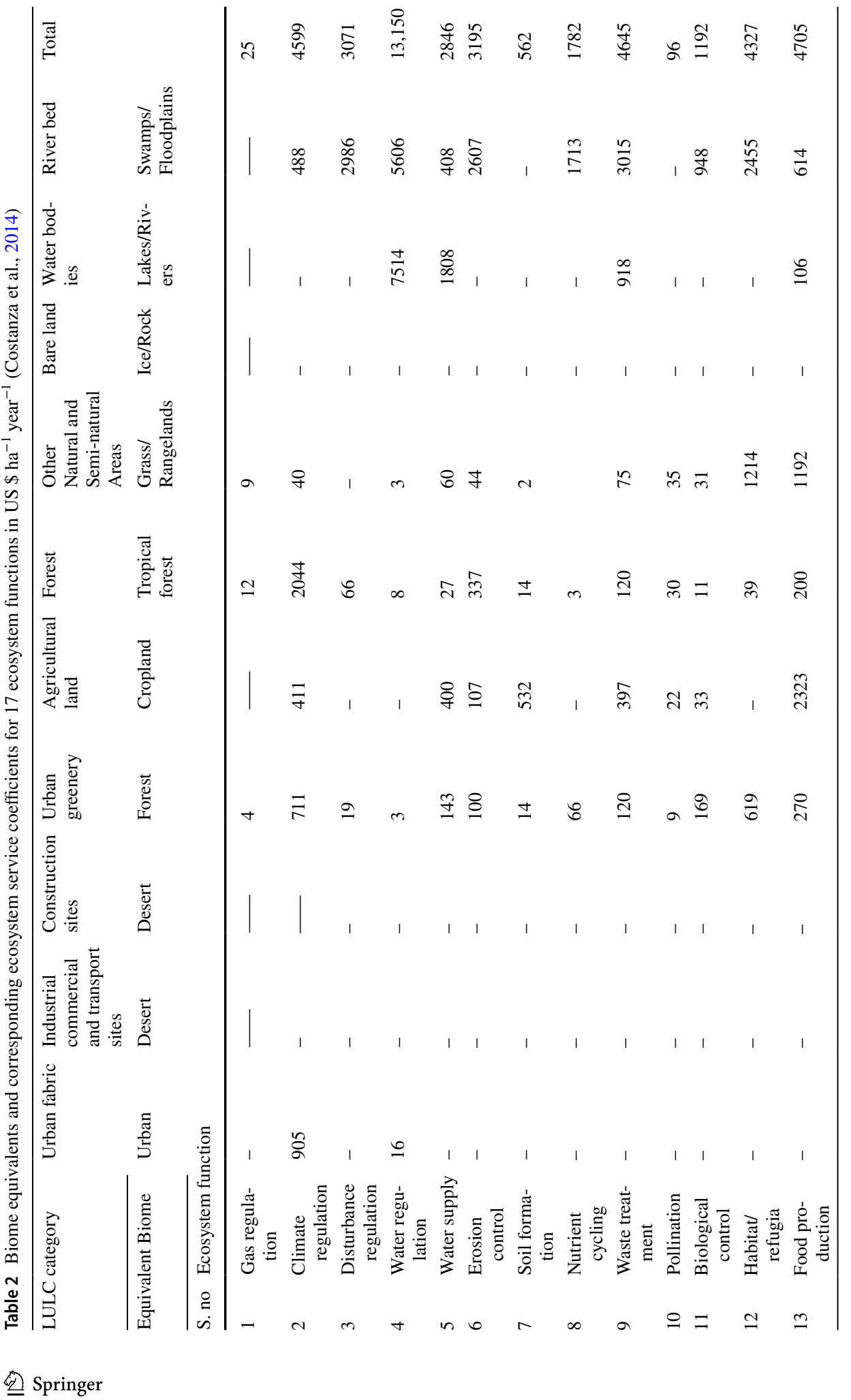




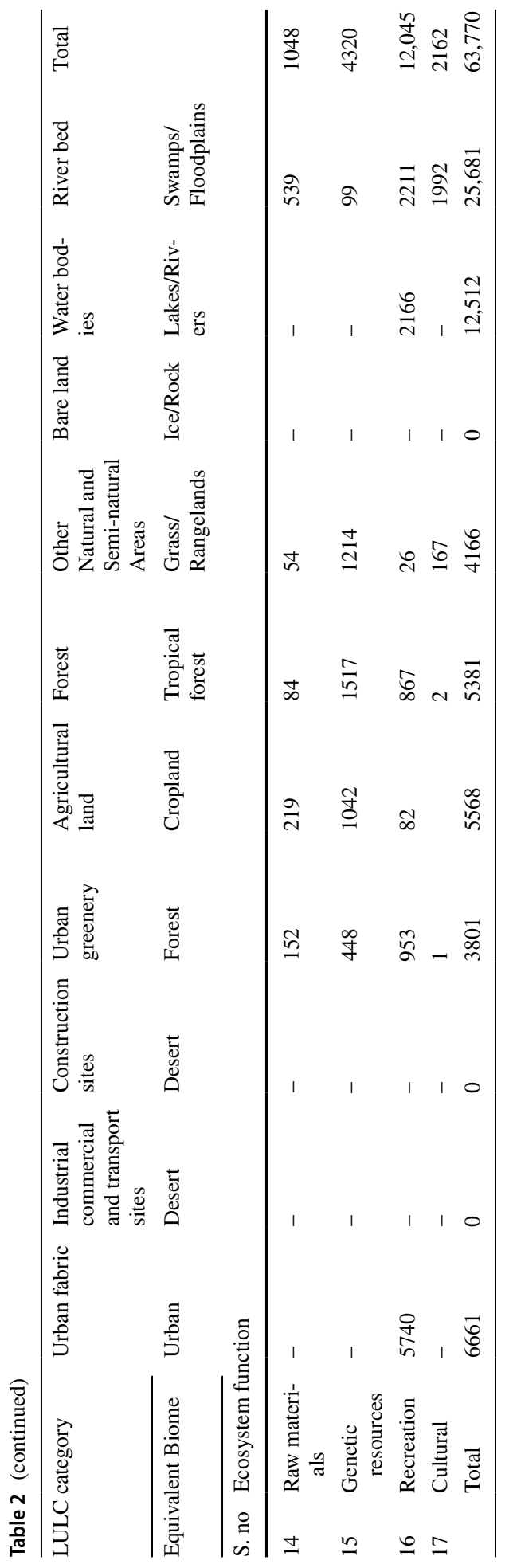




$$
M_{u i}=\left\{\left(\frac{C_{i}}{A_{t i}}\right) \times 100\right\}^{1 / n}
$$

where ' $M_{u i}$ ' is the annual percentage growth of urban land management activities in ' $i$ th' district/area, ' $C_{i}$ ' is the change in the area under urban land management activities in ' $i$ th' district/area; ' $A_{t i}$ ' is the total geographical area of the ' $i$ th' district/area and ' $n$ ' is the duration of the time period in years.

Urban sprawl can be expressed as follows:

$$
S_{u i}=\left\{\left(\frac{C_{i}}{A_{t i}}\right) \times 100\right\}^{1 / n}
$$

where ' $S_{u i}$ ' is the annual percentage growth of urban sprawl activities in 'ith' district/area, ' $C_{i}^{\prime}$ ' is the change in the area under urban sprawl activities in ' $i$ th' district/area, ' $A_{t i}$ ' is the total geographical area of the ' $i$ th' district/area and ' $n$ ' is the duration of the time period in years.

\subsection{Assignment of ecosystem service values}

The use of regional ecosystem services value coefficients would be best for monetary valuation of ecosystem services (de Groot et al., 2012; Pascual et al., 2010). There was lack of regional ecosystem services value coefficients, so we have used proxy biomes. The LULC datasets were compared with the 16 biomes identified in Costanza et al.s' (2014) ecosystem services valuation model to obtain ecosystem service values for each of the 10 land use/land cover categories (Table 2). Although the biomes used as proxy were not the perfect equals, accompanying ecosystem services value coefficients reveals the relative importance of different ecosystems in an urban area (Kreuter et al., 2001; Morya \& Punia, 2017). However, downscaling of global values in regional local assessment could provide more accurate monetary assessment of ecosystem services (Kreuter et al., 2001; de Groot et al., 2010, 2012). Specifically, the 'cropland' biome was used as a proxy for 'agricultural land', 'urban' biome for 'urban fabric', 'tropical forest' for 'forest', 'lakes/rivers' for 'water bodies', 'grass/rangelands' for 'natural and semi-natural areas', 'swamps/floodplains' for 'river bed', 'forest' for 'urban greenery', 'ice/rock' for 'bare land' and 'desert' for 'industrial, commercial, transport and construction sites' (Table 2). The estimated size of each land use/land cover category was multiplied by the value coefficient of the proxy biome to obtain the total value of the ecosystem services in the study area.

$$
\mathrm{ESV}=\sum\left(A_{k} \times \mathrm{VC}_{k}\right)
$$

where 'ESV' is the total estimated ecosystem service value, ' $A_{k}$ ' is the area (ha) and ' $\mathrm{VC}_{k}$ ' is the value coefficient (US\$/ha/year) for LULC category ' $k$ '. The change in ecosystem service values was estimated by calculating the difference between the estimated values for all LULC categories in 1992, 2003 and 2010. Absolute change was calculated by adding the changes in ecosystem services during 1992-2003 and 2003-2010. The cumulative change was assessed assuming linear change in ecosystem services during 1992-2010.

The contribution of ecosystem functions as suggested by Costanza et al. (1997, 2014) largely depends upon the practices, patterns and intensity of land use/land cover types and ecosystem health of the area (Fu et al., 2015). We have tried to measure the average 
ecosystem value of each individual ecosystem functions in generating the total ecosystem services value. The average of $\mathrm{ESV}_{f}$ of the year 1992, 2003 and 2010 was calculated to obtain average ecosystem services value $\left(\mathrm{AESV}_{f}\right)$ of the individual ecosystem functions from 1992 to 2010.

'Urban greenery' consists of homogeneousness of trees and shrubs of regular age and size; it does not have the same hierarchical structure as forests and have the lesser spectrum of ecosystem services provided by forests (e.g. climate regulation, erosion control, soil formation and genetic resources) (Chang et al., 2017; Pearse et al., 2018). Thus, the 'urban greenery' of the study area is not provided ecosystem services equal to Costanza's (2014) forest, so it has been assigned the lower value coefficient than the forests. However, 'urban greenery' provides more cultural, aesthetic and recreational ecosystem services than forest (Chang et al., 2017). Mostly tropical forest cover is found in the study area (EnviStats-India, 2018), so 'forest' has been equated with Costanza's (2014) 'tropical forest'. We should not take forest as par with the tropical rainforests of the Amazon or the Congo because of the different climatic conditions under which they occur. The 'bare land' has been assigned value equal to the 'ice/rock' because the 'bare land' is not as ecologically valuable as agricultural land. 'River bed' was considered equivalent to the floodplain, so it was assigned highest proxy value coefficient from all other categories. 'Industrial, commercial, transport and construction sites' were considered equal to the desert ecosystem. Instead, these land utilizations cause congestion, pollution and provide negligible or minimum ecosystem services leading to ecosystem disservices (Elmqvist et al., 2015; Lyytimäki et al., 2008). The use of proxy value coefficients and reliability of Costanza's (2014) estimations causes uncertainties in the total estimations but present a relative monetary assessment of different ecosystems. So, we have conducted ecosystem sensitivity analysis to determine the dependency of temporal changes in ecosystem service values on the applied valuation coefficients.

The study also assesses the changes in the ecosystem services if coefficient for each LULC category is adjusted $\pm 50 \%$ (i.e. $50 \%$ increase or decrease in coefficient). The ecosystem value coefficients for urban greenery and forest were each adjusted by $\pm 50 \%$. Even though the urban fabric, agricultural land, water bodies, river bed and other natural and semi-natural areas categories matches Costanza et al.'s (2014) definition, we also adjusted its value coefficient by $\pm 50 \%$ in the sensitivity analysis. However, because of the uncertainties about the representatives of Costanza et al.'s valuation coefficients some biomes were assigned valuation coefficients of other biomes. For example, the desert biome for industrial commercial and transport sites as well as for construction sites was considered a variant of urban fabric and was assigned the valuation coefficient US \$ 6661/hectare/ year to do the sensitivity analysis. Similarly, the urban greenery and bare land were also considered a variant of agricultural land and was assigned the valuation coefficient US \$ 5568/hectare/year to do the sensitivity analysis. In each analysis, we did sensitivity analysis using the standard economic concept of elasticity to determine the dependency of the ecosystem values on the applied coefficients, i.e. the percentage change in the output for a given percentage change in an input (Mansfield, 1985):

$$
\mathrm{CS}=\frac{\left(\mathrm{ESV}_{j}-\mathrm{ESV}_{i}\right) / \mathrm{ESV}_{i}}{\left(\mathrm{VC}_{j k}-\mathrm{VC}_{i k}\right) / \mathrm{VC}_{i k}}
$$

where 'CS' is the coefficient of sensitivity, 'VC' is the value coefficient, 'ESV' is the total estimated ecosystem service value, ' $k$ ' represents the land use/land cover category and ' $i$ ' and ' $j$ ' represent the initial and adjusted values, respectively. The robustness of 
total estimated ecosystem values is explained by the ratio between percentage change in the estimated total ecosystem value and the percentage change in the adjusted valuation coefficient. The estimated ecosystem value is elastic with respect to that adjusted valuation coefficient if the ratio is greater than 1 and inelastic if less than 1 . The use of an accurate ecosystem value coefficient becomes more critical if there is significant change in the ecosystem service value relative to the proportional change in the valuation coefficient.

\section{Results and discussion}

\subsection{Urban land management and urban sprawl estimates}

\subsubsection{Urban land management}

In NCR Delhi during 1992-2003, the annual growth rate (\%/year) of urban land management activities was $1.09 \%$ which decreased to $1.07 \%$ during 2003-2010. In NCR subregion of Haryana state, it was $1.04 \%$ which remains unchanged throughout the study period. In NCR sub-region of Uttar Pradesh state, it decreased from $1.06 \%$ to $1.04 \%$. Region-wise analysis shows that during 1992-2003 it was highest, i.e. $1.22 \%$ in NCT

Table 3 Area (hectare) under urban land management and urban sprawl activities during 1992-2003 and 2003-2010 (computed by authors)

\begin{tabular}{|c|c|c|c|c|c|c|c|c|c|}
\hline \multirow{3}{*}{$\begin{array}{l}\text { District/ } \\
\text { region }\end{array}$} & \multirow{3}{*}{$\begin{array}{l}\text { Area (hec- } \\
\text { tare) }\end{array}$} & \multicolumn{4}{|c|}{ Urban land management } & \multicolumn{4}{|c|}{ Urban sprawl } \\
\hline & & \multicolumn{2}{|c|}{$1992-2003$} & \multicolumn{2}{|l|}{$2003-2010$} & \multicolumn{2}{|c|}{$1992-2003$} & \multicolumn{2}{|c|}{$2003-2010$} \\
\hline & & Total (ha) & $\% /$ year & Total (ha) & $\% /$ year & $\begin{array}{l}\text { Total } \\
\text { (ha) }\end{array}$ & $\% /$ year & $\begin{array}{l}\text { Total } \\
\text { (ha) }\end{array}$ & $\% /$ year \\
\hline Faridabad & 83,941 & 2752 & 1.11 & 820 & 1.00 & 2297 & 1.10 & 2652 & 1.18 \\
\hline Hathin & 41,876 & 73 & 0.85 & 89 & 0.80 & 22 & 0.77 & 383 & 0.99 \\
\hline Palwal & 90,499 & 649 & 0.97 & 390 & 0.89 & 532 & 0.95 & 1022 & 1.02 \\
\hline Gurgaon & 106,309 & 2435 & 1.08 & 4025 & 1.21 & 6495 & 1.18 & 3281 & 1.17 \\
\hline Nuh & 64,072 & 232 & 0.91 & 113 & 0.78 & 103 & 0.85 & 1015 & 1.07 \\
\hline Pataudi & 22,239 & 80 & 0.91 & 33 & 0.76 & 21 & 0.81 & 101 & 0.89 \\
\hline Baghpat & 133,301 & 997 & 0.97 & 159 & 0.74 & 1273 & 1.00 & 2876 & 1.12 \\
\hline Dadri & 61,188 & 3892 & 1.18 & 2780 & 1.24 & 5304 & 1.22 & 6904 & 1.41 \\
\hline Khurja & 39,964 & 145 & 0.91 & 104 & 0.83 & 50 & 0.83 & 474 & 1.02 \\
\hline Sikandarabad & 37,564 & 121 & 0.90 & 1816 & 1.25 & 1474 & 1.13 & 3921 & 1.40 \\
\hline Ghaziabad & 74,136 & 3537 & 1.15 & 482 & 0.94 & 2764 & 1.13 & 2721 & 1.20 \\
\hline Hapur & 81,202 & 414 & 0.94 & 348 & 0.89 & 539 & 0.96 & 594 & 0.96 \\
\hline Meerut & 91,441 & 1855 & 1.07 & 1634 & 1.09 & 1449 & 1.04 & 1372 & 1.06 \\
\hline Sardhana & 59,956 & 425 & 0.97 & 306 & 0.91 & 217 & 0.91 & 649 & 1.01 \\
\hline NCT Delhi & 150,258 & 13,201 & 1.22 & 5773 & 1.21 & 6474 & 1.14 & 2340 & 1.07 \\
\hline $\begin{array}{l}\text { Haryana } \\
\text { Sub-region }\end{array}$ & 408,936 & 6221 & 1.04 & 5470 & 1.04 & 9470 & 1.08 & 8454 & 1.11 \\
\hline $\begin{array}{l}\text { Uttar Pradesh } \\
\text { Sub-region }\end{array}$ & 578,752 & 11,386 & 1.06 & 7629 & 1.04 & 13,070 & 1.08 & 19,511 & 1.19 \\
\hline NCR Delhi & $1,137,946$ & 30,808 & 1.09 & 18,872 & 1.07 & 29,014 & 1.09 & 30,305 & 1.15 \\
\hline
\end{tabular}


Delhi followed by $1.18 \%, 1.15 \%$ and $1.11 \%$ in Dadri, Ghaziabad and Faridabad, respectively. During 2003-2010, it was highest, i.e. $1.25 \%$ in Sikandarabad followed by $1.24 \%$, $1.21 \%$ and $1.21 \%$ in Dadri, NCT Delhi and Gurgaon, respectively. Over the time, the urban land management activities have increased in Sikandarabad, Gurgaon, Dadri and Meerut (Table 3).

\subsubsection{Urban sprawl}

In NCR Delhi during 1992-2003, the annual growth rate (\%/year) of urban sprawl activities was $1.09 \%$ which increased to $1.15 \%$ during 2003-2010. In NCR sub-region of Haryana state, it was $1.08 \%$ which increased to $1.11 \%$. In NCR sub-region of Uttar Pradesh state, it increased from $1.08 \%$ to $1.19 \%$. Region-wise analysis shows that during 1992-2003 it was highest, i.e. $1.22 \%$ in Dadri followed by $1.18 \%, 1.14 \%$ and $1.13 \%$ in Gurgaon, NCT Delhi and Sikandrabad, respectively. During 2003-2010 it was again highest, i.e. $1.41 \%$ in Dadri followed by $1.40 \%, 1.20 \%$ and $1.18 \%$ in Sikandarabad, Ghaziabad and Faridabad, respectively. A decrease has been observed in the urban sprawl activities in NCT Delhi and Gurgaon; apart from it, other areas indicate an increase in the rate of urban sprawl (Table 3). Over the time, the urban sprawl activities have increased in Sikandarabad and Gurgaon (Table 3).

\subsection{Land use/land cover change estimates}

The sprawl and intervention of cities critically transform the habitats of global value; particularly to the natural ecosystems within and outside the city. The major land use/land cover changes during 1992-2010 are presented in Table 5. The standard classification scheme of land use/land cover adopted by ESA has been followed for the land use/land cover classification (Table 4).

All the urban categories show an increase in the area during 1992-2010. The land category urban fabric has increased (3.27\%) from 125,246 ha in 1992 to 162,503 ha in 2010. In the study area the most affected category was agricultural land, which shrank in area from 884,438 ha in 1992 to 825,168 ha in 2010. Thus, during 1992-2010 the agricultural land and other natural and semi-natural areas have decreased $5.21 \%$ and $0.12 \%$, respectively. The National Capital Region Plan 2021 proposes orderly protection and preservation of good agricultural land and utilizing only unproductive land for urban uses. In the whole study area, forest cover has increased slightly $(0.12 \%)$ from 6228 ha in 1992 to 7566 ha in 2010. Similarly, the urban greenery has also increased from 14,672 ha in 1992 to 18,216 ha in 2010. In NCR Delhi during 1992-2010, the land category 'bare land' and 'water bodies' show marginal increase $0.03 \%$ and $0.02 \%$, respectively. In the whole study area during 1992-2010, Dadri district of Uttar Pradesh shows maximum increase (13.44\%) followed by Sikandarabad $(6.31 \%)$ and NCT Delhi (6.21\%) in urban fabric, while the minimum increase in urban fabric was estimated in Pataudi district (0.22\%) from 1992 to 2010. The NCR plan 2021 incorporates the development of urban infrastructural facilities such as transport, power, communication, drinking water, sewerage, drainage, urban greenery, etc., in metro centre, regional and sub-regional centres and central village in NCR Delhi.

During 1992-2010, the growth of industrial commercial and transport sites shows maximum increase in Dadri (3.69\%) and Gurgaon (2.73\%). During 1992-2010, the growth of industrial commercial and transport sites was estimated minimum in Khurja $(0.18 \%)$, Pataudi $(0.30 \%)$ and Hathin $(0.40 \%)$. During 1992-2010, the estimates of the construction 


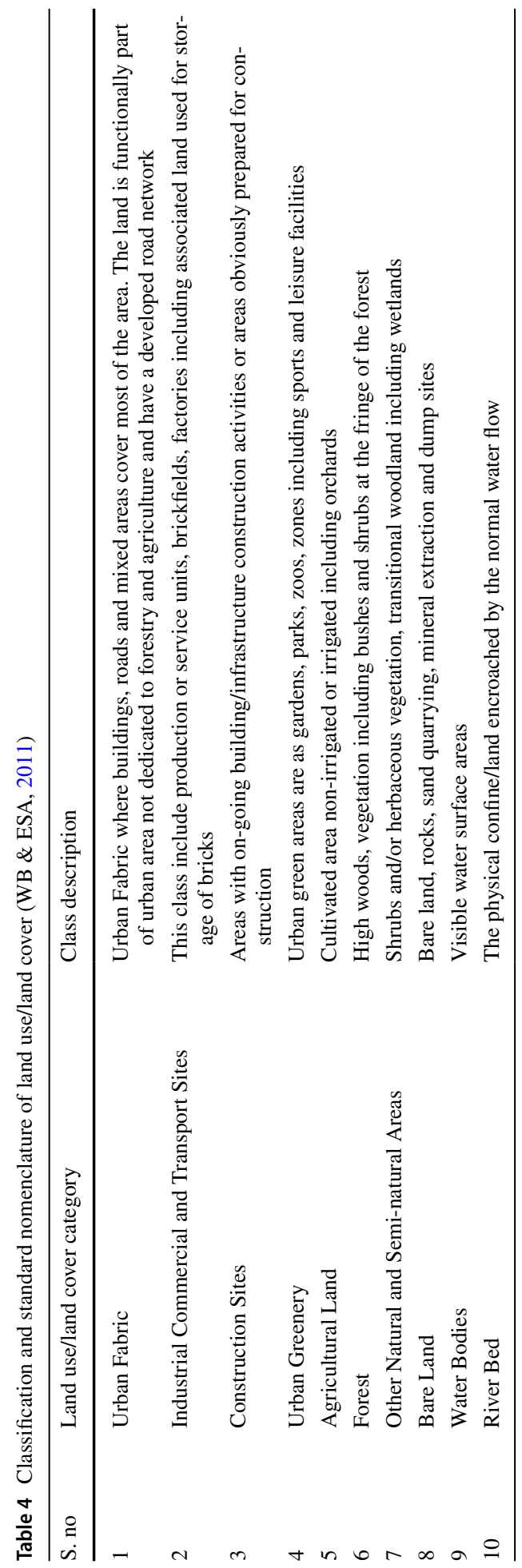




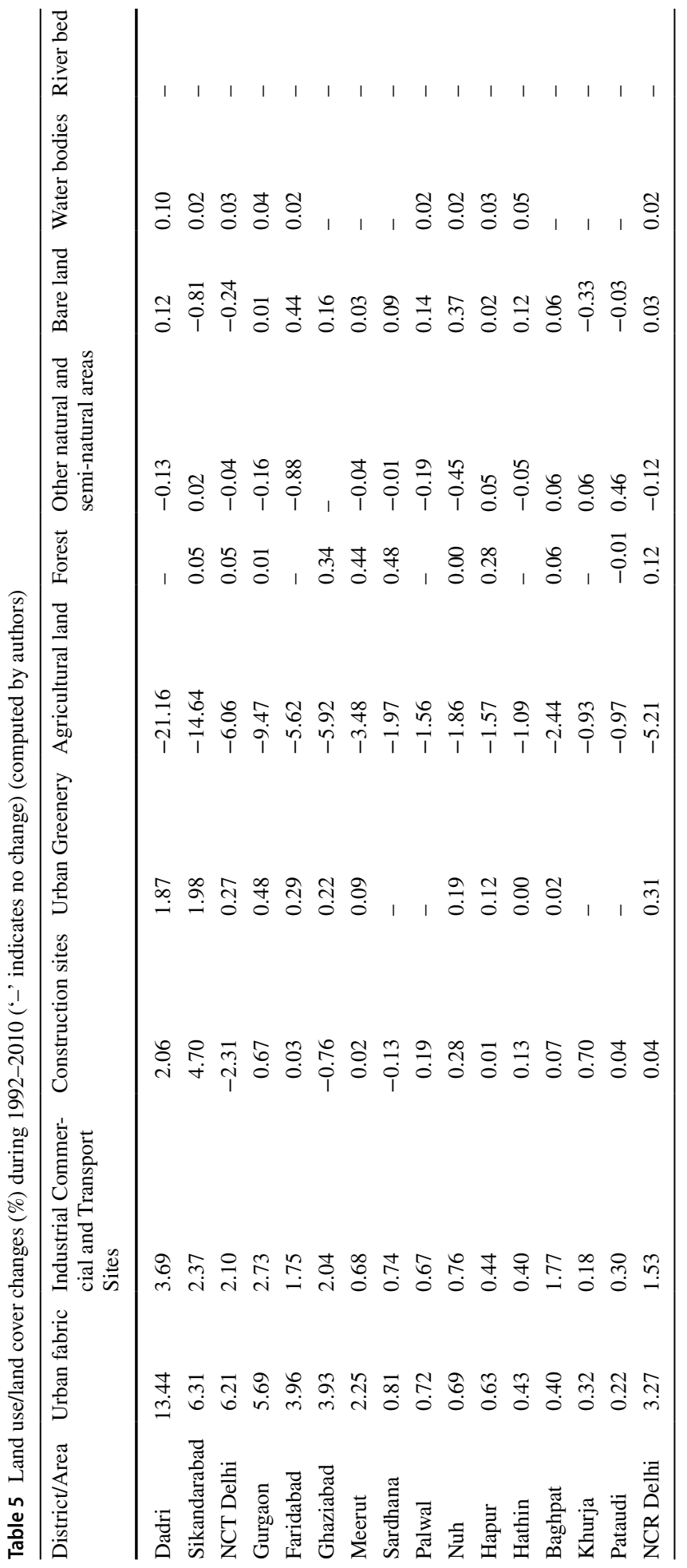


sites indicate a relatively higher increase in the construction sites in Sikandarabad (4.70\%) and Dadri districts (2.06\%). During 1992-2010, NCT Delhi and Sardhana reveal a negative growth, $-2.31 \%$ and $-0.13 \%$ in the area of construction sites. In NCT Delhi there is less availability of open lands for construction activities, and Delhi Development Authority (DDA) has imposed strong regulations regarding construction activities in NCT Delhi; this has caused a decrease in construction sites (NCRPB, 2021). During 1992-2010, the urban greenery cover has increased in the all districts/areas. During 1992-2010, the agricultural land cover has decreased in all districts/areas. The maximum decrease was in Dadri (-21.16\%) followed by Sikandarabad (-14.64\%) and Gurgaon (-9.47\%). During 1992-2010, the forest cover shows a marginal increase in all districts/areas except a slight increase in Pataudi. The bare land cover has also decreased in Sikandarabad $(-0.81 \%)$ and NCT Delhi $(-0.24 \%)$ because open land areas have been converted into built-up or construction sites (MPD, 2021), while other districts/ areas show an increase in bare land because open land areas have been converted into landfills or dump sites as well as fallow land has also increased (NCRPB, 2021). During 1992-2010, the increase in canal area has contributed to a slight increase in water bodies. During 1992-2010, the area under river bed shows no change.

\subsection{Estimation of changes in ecosystem services}

The total ecosystem service values for the year 1992, 2003 and 2010 have been calculated using the estimated land use/land cover changes and using the associated ecosystem service valuation coefficient suggested by Costanza et al. (2014). The ecosystem service value calculated for 1,137,946 hectare of our study area resulted in an average net decrease of US\$ $56 \mathrm{ha}^{-1}$ year $^{-1}(0.97 \%)$ in ecosystem services during 1992-2010. In NCR Delhi during 1992-2003, the net decrease was US\$ $16 \mathrm{ha}^{-1}$ year $^{-1}(0.28 \%)$ but during 2003-2010 the net decrease had increased to US\$ $40 \mathrm{ha}^{-1}$ year $^{-1}(0.69 \%)$ in ecosystem services. Thus, in NCR Delhi the rate of decrease in the value of ecosystem services during 2003-2010 was greater than that during 1992-2003. Assuming a linear change during 1992-2010, it represents a cumulative loss of US\$ $502.8 \mathrm{ha}^{-1}$ year $^{-1}$ in ecosystem services over the 18 years period of the study. If we calculate the absolute change by adding the change of ecosystem service during 1992-2003 and 2003-2010, we obtain an absolute loss of US\$ $285.4 \mathrm{ha}^{-1}$ year $^{-1}$. The district/area-wise analysis reveals that during 1992-2003, NCT Delhi, Ghaziabad, Meerut, Hathin, Faidabad, Nuh and Pataudi indicate an increase in the value of ecosystem services (Table 6).

During 1992-2003 in all districts/areas, NCT Delhi shows highest rate of increase (i.e. $0.084 \%$ or US\$ $52 \mathrm{ha}^{-1}$ year $^{-1}$ ) and Gurgaon shows highest rate of decrease (i.e. $-0.254 \%$ or US\$ $147 \mathrm{ha}^{-1}$ year $^{-1}$ ). During 2003-2010, only NCT Delhi and Gurgaon show an increase in the total value of ecosystem services. During 2003-2010 in all districts/ areas, NCT Delhi shows highest rate of increase (i.e. $0.097 \%$ or US\$ $39 \mathrm{ha}^{-1} \mathrm{year}^{-1}$ ) and Sikandarabad showed highest rate of decrease (i.e. $-0.328 \%$ or US\$ $166 \mathrm{ha}^{-1}$ year $^{-1}$ ). Overall during 1992-2010, only NCT Delhi indicates an increase and rest other districts/areas indicate decrease in the total estimated value of ecosystem services. In the whole study period of 18 years, NCT Delhi indicates highest rate (i.e. $0.089 \%$ or US\$ $91 \mathrm{ha}^{-1} \mathrm{year}^{-1}$ ) and Sikandarabad indicates highest rate of decrease (i.e. $-0.238 \%$ or US\$ $314 \mathrm{ha}^{-1} \mathrm{year}^{-1}$ ) in the value of ecosystem services. If we assume a linear change from 1992 to 2010, NCT Delhi measures maximum cumulative gain (i.e. US\$ $817.4 \mathrm{ha}^{-1}$ year $^{-1}$ ) and Sikandarabad measures maximum cumulative loss (i.e. US\$ $2822.2 \mathrm{ha}^{-1}$ year $^{-1}$ ) in ecosystem services 


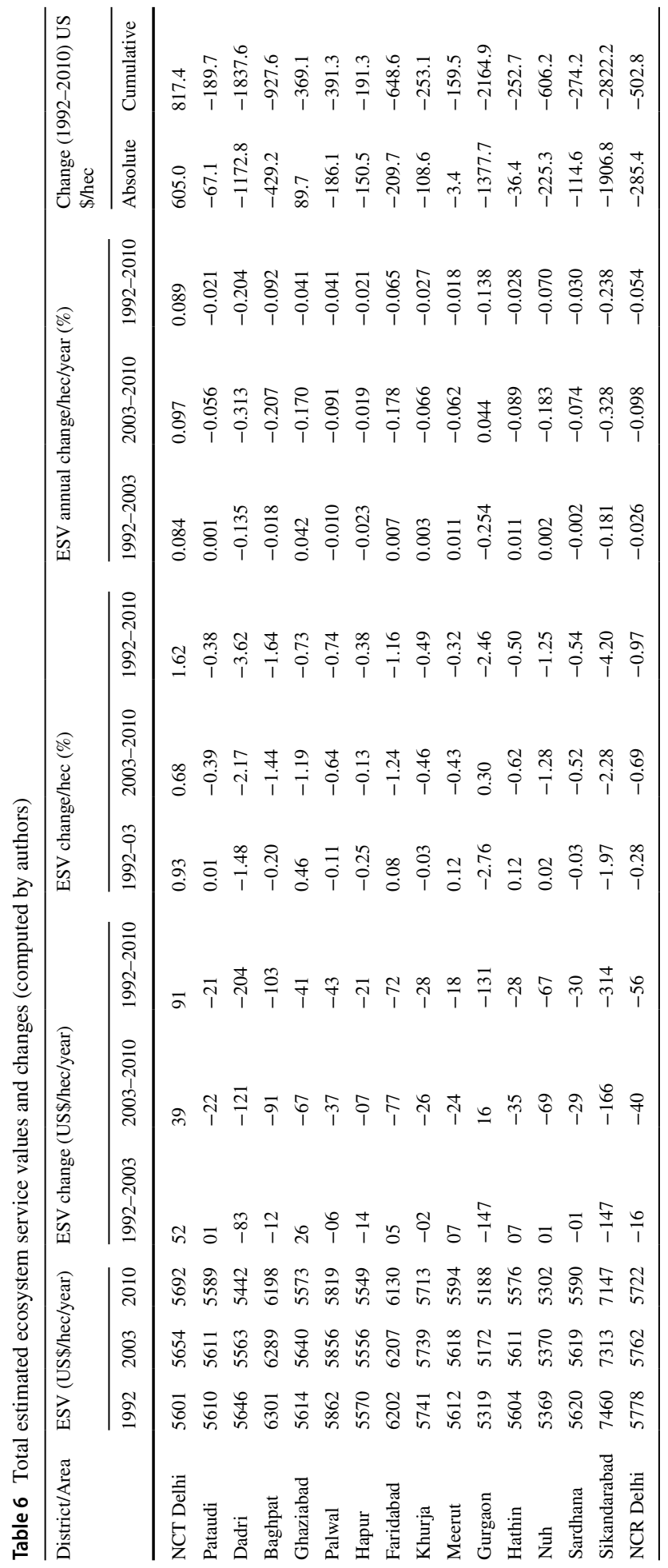


over the 18 years period of study. If we calculate the absolute change by adding the change of ecosystem service during these two time periods (i.e. 1992-2003 and 2003-2010), we obtained maximum absolute gain in NCT Delhi (i.e. US\$ $605 \mathrm{ha}^{-1} \mathrm{year}^{-1}$ ) and maximum absolute loss of (i.e. US\$ $1906.8 \mathrm{ha}^{-1}$ year $^{-1}$ ) in Sikandarabad district (Table 6). During 2003-2010 in NCR Delhi, the rate of decrease in the total ecosystem services value was $-0.026 \% \mathrm{ha}^{-1}$ year $^{-1}$ which increased to $-0.098 \%$ during 2003-2010. In the study area during 1992-2010, the rate of decrease in the total ecosystem services value is measured as $-0.054 \% \mathrm{ha}^{-1}$ year $^{-1}$ and it's continuously increasing.

The land use/land cover categories 'industrial, commercial, transport sites and construction sites' were assigned value coefficient equivalent to the desert biome, and the LULC category 'bare land' was assigned the value coefficient equivalent to the ice/rock biome (Table 2). According to the Costanza's (2014), the desert biome and the ice/rock biome contribute nothing in global ecosystem services, so the LULC categories 'industrial, commercial and transport sites, construction sites' and 'bare land' provide no ecologically beneficially values. Assigning a value would have had a significant effect on our estimates of ecosystem services because these LULC categories cover a significant portion of the study area. In summary, in NCR Delhi over the 18-year period, the decrease of 59,270 hectare of agricultural land and increase of 37,257 hectare of urban fabric appeared to have resulted in a massive change to the total estimated annual value of ecosystem services. The water resources Yamuna River and Hindon River are already polluted and in the deteriorating condition and other ephemeral drains have extinct due to illegal encroachment (CPCB, 2000). It is expected that the capacity of water bodies to provide ecosystem services will decrease over the time.

\subsection{Ecosystem function analysis}

In addition to estimating land use/land cover change effects on the total value of ecosystem services, we also estimated the impacts of land use/ land cover change on the 17 ecosystem functions suggested by Costanza et al. The average of ' $\mathrm{ESV}_{f}$ ' of the year 1992, 2003 and 2010 was calculated to obtain average ecosystem services value $\left(\mathrm{AESV}_{f}\right)$ of the individual ecosystem functions from 1992 to 2010 .

We have evaluated the contribution of ecosystem functions based on their estimated $\mathrm{ESV}_{f}$ to overall value of ecosystem services in each year 1992, 2003 and 2010. Figure 3 shows the contribution of 17 ecosystem functions in the total ecosystem services value of the study area during 1992-2010. The contribution of the ecosystem function 'food production' has dominated followed by 'genetic resources' over the 18-year study period. The ecosystem functions 'food production', 'genetic resources' and 'recreation' generate more than $60 \%$ of the total ecosystem services (Fig. 3). The contribution of ecosystem functions 'climate regulation' and 'recreation' has increased, while the contribution of ecosystem functions 'water supply', 'soil formation', 'waste treatment', 'food production', 'raw materials' and 'genetic resources' has decreased over the time. No change was observed in the supply of ecosystem services by the ecosystem functions 'gas regulation', 'disturbance regulation', 'water regulation', 'erosion control', 'nutrient cycling' 'pollination', 'biological control', 'habitat/refugia' and 'cultural'.

Table 7 shows the contribution of the 17 ecosystem functions in the total ecosystem services value of the each district/area during 1992-2010. The ecosystem function 'food production' is the dominant ecosystem function in the whole study area except in NCT Delhi. The 'recreation' and 'climate regulation' are the dominant ecosystem functions in NCT 


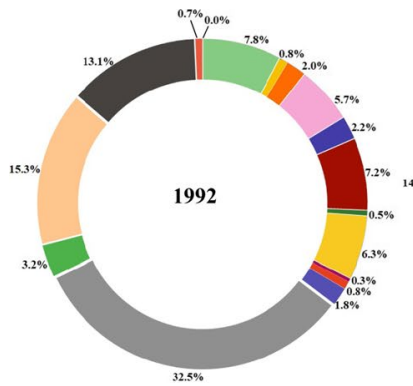

was regulation

- Soil formation

Food production

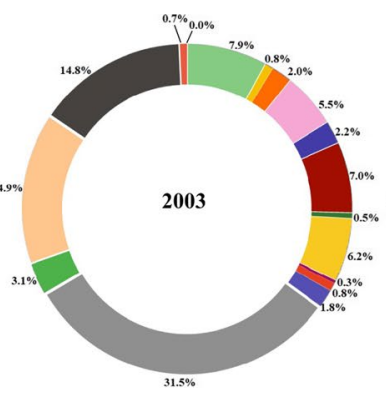

= Disturbance regulation = Water regulation

w Waste treatment

- Genetic resources

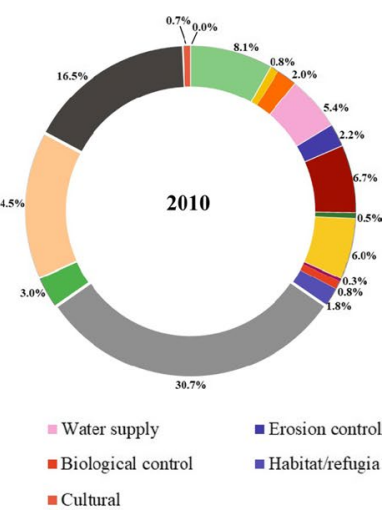

Fig. 3 Ecosystem services value (\%) of the individual ecosystem function in the year 1992, 2003 and 2010 (authors work)

Delhi as well as in whole study area. Table 7 reveals that the contribution of ecosystem functions 'soil formation' and 'food production' is comparatively highest in Pataudi district than other districts/area. The average ecosystem service value of the ecosystem function 'habitat/refugia' was measured highest in Faridabad district because 'other natural and semi-natural areas' is a dominant land category there. The average ecosystem service values of the ecosystem functions 'raw materials' and 'water supply' were measured highest in Khurja and Hathin, respectively. The average ecosystem service values of the ecosystem functions 'gas regulation', 'pollination' and 'genetic resources' were measured highest in Nuh district. The average ecosystem service values of the ecosystem functions 'disturbance regulation', 'water regulation', 'erosion control', 'nutrient cycling', 'waste treatment', biological control' and 'cultural' were measured highest in Sikandarabad district rather other districts/areas.

\subsection{Ecosystem services sensitivity analysis}

The sensitivity analysis reveals the level to which the total ecosystem services are affected if an alternative value coefficient is assigned for a particular land use/land cover, so the changes in total ecosystem services value were examined using the alternative ecosystem value coefficient ( $\pm 50 \%$ change in the coefficient). The river bed is assigned a very high valuation coefficient (US\$ 25,681/ha/year), but it has not affected as the area of this category has remained unchanged during 1992-2010. The value coefficient assigned to the land category 'river bed' is almost, 6 times of the ecosystem value coefficient assigned to the 'other natural and semi-natural areas including wetlands', 8.5 of the ecosystem value coefficient assigned to the 'urban greenery', and 4 times of the ecosystem value coefficient assigned to the 'urban fabric' (Table 2). However, the high value coefficient of river bed category has underestimated value coefficients of other land use/land cover categories. For NCR Delhi the effects of using alternative ecosystem value coefficient $( \pm 50 \%$ change in the coefficient) to estimate total ecosystem service values in 1992, 2003 and 2010 are shown in Table 8.

Adjustment to the value coefficient for urban greenery, forest, water bodies and other natural and semi-natural areas categories had very little effect on the estimates of total ecosystem service values $( \pm 0.25 \%$ to $\pm 1.68 \%$ change for a $\pm 50 \%$ change in value 


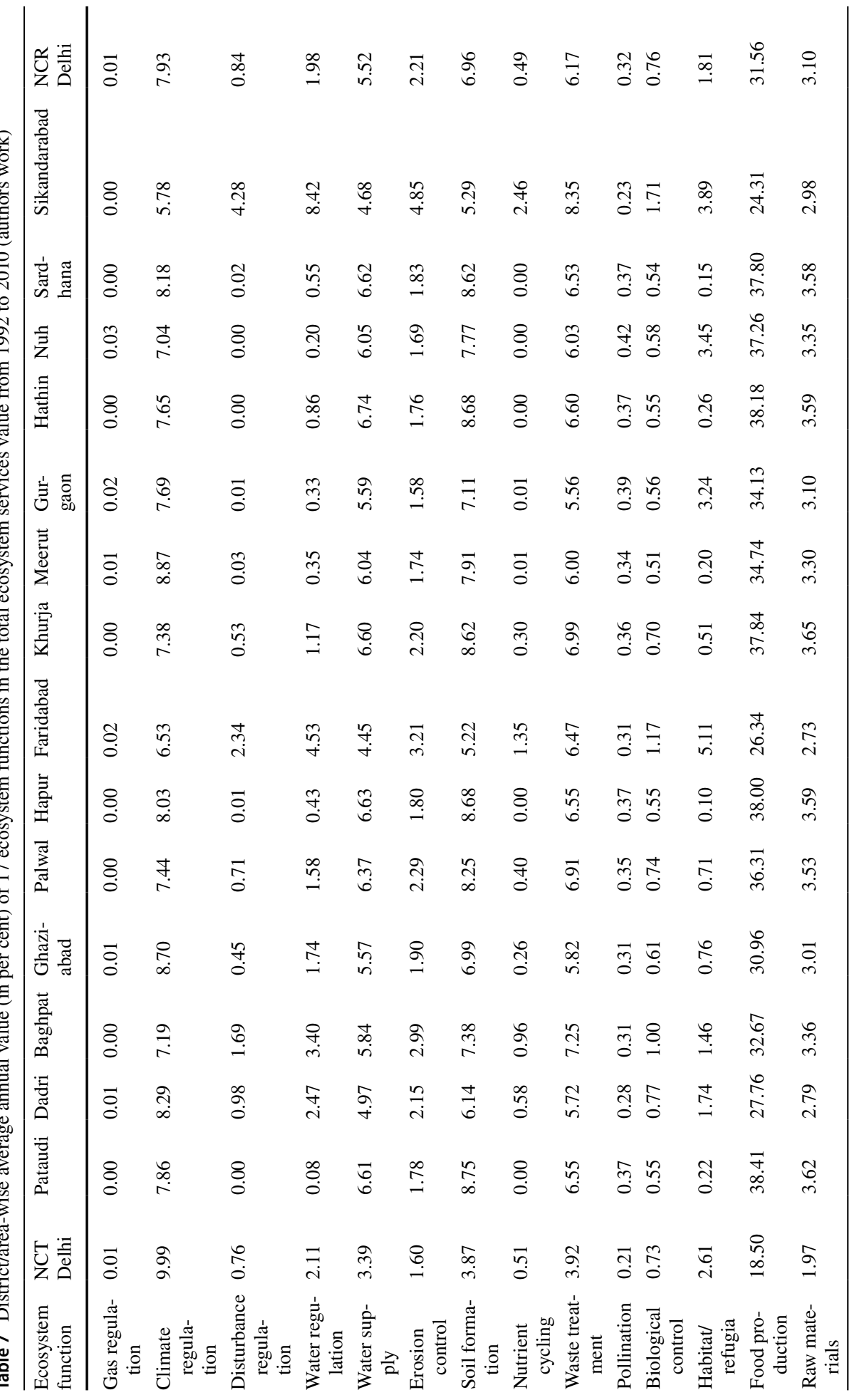




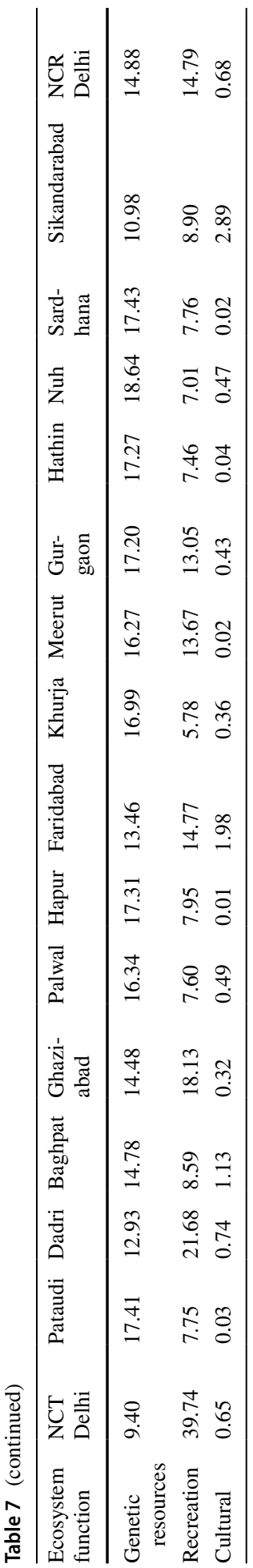


Table 8 Percentage change in estimated total ecosystem service value and coefficient of sensitivity (CS) resulting from adjustment of ecosystem valuation coefficients $(V C)$ (authors work)

\begin{tabular}{|c|c|c|c|c|c|c|}
\hline \multirow[t]{2}{*}{ Change in valuation coefficient } & \multicolumn{2}{|l|}{1992} & \multicolumn{2}{|l|}{2003} & \multicolumn{2}{|l|}{2010} \\
\hline & $\%$ & $C S$ & $\%$ & $C S$ & $\%$ & $C S$ \\
\hline Urban Fabric $V C \pm 50$ & \pm 6.34 & 0.127 & \pm 7.35 & 0.147 & \pm 8.31 & 0.166 \\
\hline Urban Greenery $V C \pm 50$ & \pm 0.42 & 0.008 & \pm 0.48 & 0.010 & \pm 0.53 & 0.011 \\
\hline Agricultural Land $V C \pm 50$ & \pm 37.44 & 0.749 & \pm 36.35 & 0.727 & \pm 35.27 & 0.706 \\
\hline Forest $V C \pm 50$ & \pm 0.25 & 0.005 & \pm 0.30 & 0.006 & \pm 0.31 & 0.006 \\
\hline Other Natural and Semi-natural Areas $V C \pm 50$ & \pm 1.68 & 0.034 & \pm 1.64 & 0.033 & \pm 1.65 & 0.033 \\
\hline Water Bodies $V C \pm 50$ & \pm 0.32 & 0.006 & \pm 0.32 & 0.006 & \pm 0.34 & 0.007 \\
\hline River Bed $V C \pm 50$ & \pm 3.53 & 0.071 & \pm 3.54 & 0.071 & \pm 3.56 & 0.071 \\
\hline Urban Greenery $V C=$ Forest $V C$ & +0.35 & 0.008 & +0.40 & 0.010 & +0.44 & 0.011 \\
\hline Forest $V C=$ Urban Greenery $V C$ & -0.15 & 0.005 & -0.18 & 0.006 & -0.18 & 0.006 \\
\hline $\begin{array}{l}\text { Industrial Commercial and Transport Sites } \\
\qquad C=\text { Urban Fabric } V C\end{array}$ & +1.26 & - & +1.84 & - & +3.05 & - \\
\hline Construction Sites $V C=$ Urban Fabric $V C$ & +1.70 & - & +1.92 & - & +1.77 & - \\
\hline Bare Land $V C=$ Agricultural Land $V C$ & +0.30 & - & +0.22 & - & +0.33 & - \\
\hline
\end{tabular}

coefficient). The coefficient of sensitivity ranged from a 0.005 to 0.034 for urban greenery, forest, water bodies and other natural and semi-natural areas categories. The relatively low coefficients of sensitivity values reflect the fact that the area and/or the value coefficients associated with these LULC types are relatively small and suggest that this ecosystem value estimate is reasonably robust. However, when the urban fabric coefficient was changed $\pm 50 \%$, the total ecosystem service value changed $\pm 6.34 \%, \pm 7.35 \%$ and $\pm 8.31 \%$ in 1992,2003 and 2010 , respectively. When the agricultural land coefficient was changed $\pm 50 \%$, the total ecosystem service value changed $\pm 37.44 \%, \pm 36.35 \%$ and $\pm 35.27 \%$ in 1992, 2003 and 2010, respectively. In NCR Delhi due to the extensive cover of agricultural land, the corresponding $C S$ for this land cover category was high, ranging from 0.706 to 0.749 .

Due to the uncertainty about the relative ecological value of urban greenery and forest, perhaps most relevant was the result of the sensitivity analysis in which the urban greenery coefficient was equated to that of forest (US\$ $5381 \mathrm{ha}^{-1}$ year $^{-1}$ ), the underlying assumption being that the transformation of urban greenery to forest results in $0.35 \%$ (1992), $0.40 \%$ (2003) and $0.44 \%$ (2010) increase in total estimated ecosystem services. The $C S$ for 'urban greenery' coefficient change was ranging from 0.008 to 0.011 explaining that the estimated ecosystem service value is inelastic if urban greenery coefficient is equated to forest coefficient. Similarly, if the forest coefficient was equated to that of urban greenery (US\$ $3801 \mathrm{ha}^{-1}$ year $^{-1}$ ), the underlying assumption is that the transformation of forest to urban greenery results in $0.15 \%$ (1992), $0.18 \%$ (2003) and $0.18 \%$ (2010) decrease in total estimated ecosystem services. It indicates that highly adjusted coefficients or a significant change in any land category can substantially affect the accuracy of estimated changes in ecosystem service values over time. The sensitivity analysis in which the industrial, commercial and transport sites coefficient was equated to that of urban fabric resulted in $1.26 \%$, $1.84 \%$ and $3.95 \%$ increase in the annual value of ecosystem services in 1992, 2003 and 2010 , respectively. 
Similarly, when construction sites coefficient is equated to that of urban fabric, it results in $1.70 \%, 1.92 \%$ and $1.77 \%$ increase in the annual value of ecosystem services in 1992 , 2003 and 2010, respectively. When value coefficient of bare land is equated with agricultural land, it results in very insignificant changes in the total ecosystem services. The estimated value of the ecosystem service value for the study area changed from a low of $0.005 \%$ for $1 \%$ change in the value of the forest coefficient, to a high of $0.749 \%$ for a $1 \%$ change in the value of the agricultural land coefficient. The ecosystem service sensitivity analysis reveals that the estimated ecosystem services value for each land use/land cover category is inelastic or robust with respect to that value coefficient. The ecosystem service sensitivity analysis emphasizes the use of accurate value coefficients rather than proxy values, especially for dominant land use/land cover categories.

\section{Conclusion}

In recent decades, the inflow and investment of capital, better urban management practices, improved employment growth and economic opportunities have led to a high rate of population growth in the NCR Delhi. In NCR Delhi the urban sprawl activities are more active than urban land management activities. The rate of urban land management is linear in NCR sub-region of Haryana state, but it was higher in the NCR sub-region of Uttar Pradesh state. The rate of sprawl of urban phenomena is higher in NCR sub-region of Uttar Pradesh than NCR sub-region of Haryana state. The urban land management activities are increasing in the core (ex. NCT Delhi). It indicates densification of the urban phenomena in the core of the NCR Delhi. The increasing rate of urban sprawl in the areas except NCT Delhi and Gurgaon indicates sprawl of urban phenomena in these areas. Urban sprawl activities are decreasing in the core but are increasing in the peripheral reason. The regions Dadri and Sikandarabad are experiencing densification as well as sprawl of the urban phenomena. The million-plus cities Ghaziabad and Faridabad are also experiencing sprawl more than the densification of urban phenomena. The urban fabric and industrial, commercial and transport sites have increased significantly within 18-year time period. The urban developmental activities are largely dependent on the consumption of ecosystem services generating in the hinterland. Thus, an increase in industrial, commercial and construction activities is expected to increase pollutant load and deteriorate environmental quality of the area. This indicates that urban developmental activities are providing ecosystem services as well as ecosystem disservices that need to be measured for the better valuation of the total ecosystem services. The significant loss of agricultural land due to reclamation activities is expected to intensify pressure on the agricultural land through increasing fertilizer and water use intensity.

The control on the urban growth is the first priority to stop encroachment on other ecosystems. There is need for development and decentralization of localized economic opportunities in the other places so people do not migrate to the NCR suburb. Apart from it in the NCR Delhi, there is need to prioritize the conservation and protection of natural ecosystems (forest, water) and rigorous land use plans to minimize the human interference in suburb ecosystems. The water resources of the area are not capable to provide as much ecosystem services as the fresh blue spaces could so the valuation of ecosystem functions provided by the water bodies may be overly estimated. There is need to protect the Yamuna River and Hindon River beds of critical value from the urban encroachments. The check on urban growth and sprawl should be followed by the maintenance of ecosystems 
to maximize the ecological benefits in the NCR urban area. The sensitivity analysis results show that conversion of urban greenery into dense forest cover can provide more ecosystem services. So, it is required to develop open spaces or bare land into urban green belts and denser forest covers to improve the ecological benefits of the green spaces. It is estimated in NCR Delhi the contribution of ecosystem functions, climate regulation and recreation is expected to increase while the contribution of ecosystem functions having critical importance like water supply, soil formation, waste treatment, food production, raw materials and genetic resources will decrease over the time. It will not be practical to stop all reclamation or conversion activities but the future LULC changes can be based on rigorous environmental impact analyses. This will require monitoring of LULC changes at regular intervals and rigours implementation of National Capital Region Plan in the perspective of environmental conservation. In future researches, the analysis based on the location specific valuation coefficients can be integrated with more rigorous GIS techniques for efficient and accurate estimations of the impact of land use conversion on the ecosystem services.

Acknowledgements We would like to convey our sincere thanks to World Bank (WB), European Space Agency (ESA) and GISAT for providing and allowing public use of the earth observation data related to 'Historical Assessment of Spatial Growth of Built-ups in Metropolitan areas of Delhi and Mumbai in India and Dhaka in Bangladesh'.

\section{Declaration}

Conflict of interest I certify that the article is our original work, and it has been neither published or contain any material written by another person except where due acknowledgement is made in the text. There is no conflict of interest, and we take full responsibility of the article.

\section{References}

Alberti, M., \& Marzluff, J. M. (2004). Ecological resilience in urban ecosystems: Linking urban patterns to human and ecological functions. Urban Ecosystems, 7, 241-265. https://doi.org/10.1023/B:UECO. 0000044038.90173.c6

Alberti, M., Marzluff, J. M., Shulenberger, E., Bradley, G., Ryanand, C., \& Zumbrunnen, C. (2003). Integrating humans into ecology: Opportunities and challenges for studying urban ecosystems. BioScience, 53, 1169-1179.

Angel, S., Parent, J., Civco, D. L., Blei, A., \& Potere, D. (2011). The dimensions of global urban expansion: Estimates and projections for all countries, 2000-2050. Progress in Planning, 75(2), 53-107. https:// doi.org/10.1016/j.progress.2011.04.001

Balvanera, P., Kremen, M. C., \& Martínez-Ramos, M. (2005). Applying community structure analysis to ecosystem function: Examples from pollination and carbon storage. Ecological Applications, 15(1), 360-375.

Castro, A. J., Martín-Lopez, B., García-Llorente, M., Aguilera, P. A., López, E., \& Cabello, J. (2011). Social preferences regarding the delivery of ecosystem services in a semiarid Mediterranean region. The Journal of Arid Environments, 75(11), 1201-1208.

Census of India, (2011). Provisional Population Totals-Urban Agglomerations and Cities. Available online: http://censusindia.gov.in/2011-prov-results/paper2/data_files/India2/1.\%20Data\%20Highlight. pdf.

Chang, J., Qu, Z., Xu, R., Pan, K., Xu, B., Min, Y., Ren, Y., Yang, G., \& Ge1, Y. . (2017). Assessing the ecosystem services provided by urban green spaces along urban center-edge gradients. Scientific Reports, 7-11226, https://doi.org/10.1038/s41598-017-11559-5

Chee, Y. (2004). An ecological perspective on the valuation of ecosystem services. Biological Conservation, 120, 549-565. https://doi.org/10.1016/j.biocon.2004.03.028

Costanza, R., d'Arge, R., De Groot, R. S., Farber, S., Grasso, M., Hannon, B., Limburg, K., Naeem, S., O’Neill, R. V., Paruel, J., Raskin, R. G., Sutton, P., \& Van den Belt, M. (1997). The value of the world's ecosystem service and natural capital. Nature, 387, 253-260. 
Costanza, R., de Groot, R., Sutton, P., van der Ploeg, S., Anderson, S. J., Kubiszewski, I., Farber, S., \& Turner, R. K. (2014). Changes in the global value of ecosystem services. Global Environmental Change, 26, 152-158.

CPCB, (2000). Central Pollution Control Board,Water quality status of Yamuna river. Assessment and Development of River Basin Series, ADSORBS/32/1999-2000.New Delhi: Ministry of Environment Forests; 2000.

Daily, G. C. (1997). Nature's services. Societal Dependence on Natural Ecosystems; Island Press.

de Groot, R.S., Kumar, P., van der Ploeg, S., Sukhdev, P. (2010). Estimates of monetary values of ecosystem services. In: Kumar, P. (Ed.), TEEB Foundations, The Economics of Ecosystems and Biodiversity: Ecological and Economic Foundations, Eds. Earthscan, London (Annex 3).

de Groot, R., Brander, L., van der Ploeg, S., Costanza, R., Bernard, F., Braat, L., Christie, M., Crossman, N., Ghermandi, A., Hein, L., Hussain, S., Kumar, P., McVittie, A., Portela, R., Rodriguez, L. C., ten Brink, P., \& van Beukering, P. (2012). Global estimates of the value of ecosystems and their services in monetary units. Ecosystem Services, 1, 50-61.

Elmqvist, T., Setälä, H., Handel, S. N., van der Ploeg, S., Aronson, J., Blignaut, J. N., Gómez-Baggethun, E., Nowak, D. J., Kronenberg, J., \& de Groot, R. (2015). Benefits of restoring ecosystem services in urban areas. Current Opinion in Environmental Sustainability, 14, 101-108.

EnviStats-India. (2018). Central Statistics Office (CSO). Ministry of Statistics \& Programme Implementation, Government of India, New Delhi.

Everarda, M., Johnstonb, P., Santillob, D., \& Staddon, C. (2020). The role of ecosystems in mitigation and management of Covid-19 and other zoonoses. Environmental Science and Policy., 111, 7-17.

Fedele, G., Locatelli, B., Djoudi, H., \& Colloff, M. J. (2018). Reducing risks by transforming landscapes: Cross-scale effects of land-use changes on ecosystem services. PLoS ONE, 13(4), e0195895. https:// doi.org/10.1371/journal.pone.0195895

Fu, B., Zhang, L., Xu, Z., Zhao, Y., Wei, Y., \& Skinner, W. (2015). Ecosystem services in changing land use. Journal of Soils and Sediments, 15, 833-843. https://doi.org/10.1007/s11368-015-1082-X

GISAT. (2011). Historical Assessment of Spatial Growth of Built-ups and Metropolitan areas of Delhi and Mumbai in India, and Dhaka in Bangladesh. Technical note and GIS maps, World Bank, Washington DC and European Space Agency (ESA), Earth obsevations for development, Paris.

Grimm, N. B., Faeth, S. H., Golubiewski, N. E., Redman, C. L., Wu, J., Bai, X., Briggs, J., \& Golubiewski. N. B. (2008). Global change and the ecology of cities. Science, 319, 756-760.

Haines-Young R., \& Potschin M. (2010). The links between biodiversity, ecosystem services and human wellbeing. Ecosyst Ecol A new Synth, 110-139. https://doi.org/10.1017/9780511750458.007

Kreuter, U. P., Harris, H. G., Matlock, M. D., \& Lacey, R. E. (2001). Change in ecosystem service values in the San Antonio area, Texas. Ecological Economics, 39, 333-346.

Lambin, E. F., Turner, B. L., II., Geist, H. J., Agbola, S., Angelsen, A., Bruce, J. W., Coomes, O., Dirzo, R., Fischer, G., Folke, C., George, P. S., Homewood, K., Imbernon, J., Leemans, R., Li, X., Moran, E. F., Mortimore, M., Ramakrishnan, P. S., Richards, J. F., Skånes, H., Will Steffen, E., Stone, G D., Svedin, U., Veldkamp, T.A., Vogel, C., Xu, J. (2001). The causes of land-use and land-cover change: Moving beyond the myths. Global Environmental Change, 4, 261-269.

Lyytimäki, J., Kjerulf Petersen, L. K., Normander, B., \& Bezák, P. (2008). Nature as a nuisance? Nature as a nuisance? Ecosystem services and disservices to urban lifestyleEnvironmental Sciences, 5(3), 161172. https://doi.org/10.1080/15693430802055524

Mansfield, E. (1985). Microeconomics: Theory and Applications (5th ed.). W.W. Norton and Company.

Master Plan of Delhi (MPD)-2021. (2010). Delhi Development Authority. New Delhi: Delhi Development Authority. DDA.

Martín-L'opez, B., et al. (2012). Uncovering ecosystem services bundles through social preferences. PLoS One, 7(6), e38970.

McClanahan, T. R. (2009). The Effects of Coral Bleaching on Coral Reef Fish, Fisheries, and Ecosystem Services in the Western Indian Ocean. MASMA Final Technical Report. WIOMSA Book Series No. 9, viii + 52pp.

Millennium Ecosystem Assessment (MEA). (2005). Ecosystems and Human Well-being: Synthesis. Island Press.

Morya, C.P., Punia M. (2017). Ecosystem Services in NCT Delhi. S.S. Acharya et al. (eds.), Marginalization in Globalizing Delhi: Issues of Land, Livelihoods and Health. pp81-96. https://doi.org/10.1007/ 978-81-322-3583-5

Morya, C. P., \& Ram, M. (2019). Dynamics of suburbanization and influence of National Capital Territory of Delhi on towns. GeoJournal. https://doi.org/10.1007/s10708-019-10052-y 
Müller, N., Ignatieva, M., Nilon, C. H., Werner, P., \& Zipperer, W. C., et al. (2013). Patterns and trends in urban biodiversity and landscape design. In T. Elmqvist (Ed.), Urbanization, Biodiversity and Ecosystem Services: Challenges and Opportunities (pp. 123-174). Springer.

Nagendra, H., Sudhira, H. S., Katti, M., \& Schewenius, M., et al. (2013). Sub-regionalassessment of India: Effects of urbanization on land use, biodiversity and ecosystem services. In T. Elmqvist (Ed.), Urbanization, Biodiversity and Ecosystem Services: Challenges and Opportunities (pp. 65-74). Springer.

Nagendra, H., Sudhira, H. S., Katti, M., Tengo, M., \& Schewenius, M. (2014). Urbanization and its impacts on land use, biodiversity and ecosystems in India. Interdisciplinia, 2, 305-313.

NCRPB, (2021). Regional Plan- 2021 for National Capital Region. New Delhi; National capital Planning Board, Ministry of Urban Development, Government of India; 2005.

Pascual, U., Muradian, R., Brander, L., Gómez-, B. E., Martín-López, B., Verma, M., Armsworth, P., Christie, M., Cornelissen, H., Eppink, F., Farley, J., Loomis, J., Pearson, L., Perrings, C., \& Polasky, S. (2010). Chapter 5: The economics of valuing ecosystem services and biodiversity. In R. Kumar (Ed.), The economics of ecosystems and biodiversity: Ecological and economic foundations (pp. 183-256). Routledge.

Pearse, W. D., Bares, J. C., Hobbie, S. E., Avolio, M. L., Bettez, N. D., Chowdhury, R. R., et al. (2018). Homogenization of plant diversity, composition, and structure in North American urban yards. Ecosphere, 9, e02105. https://doi.org/10.1002/ecs2.2105

Shackleton, C. M., Ruwanza, S., Sinasson Sanni, G. K., Bennett, S., De Lacy, P., Modipa, R., Mtati, N., Sachikonye, M., \& Thondhlana, G. (2016). Unpacking Pandora's Box: Understanding and categorising ecosystem disservices for environmental management and human wellbeing. Ecosystems, 19, 587-600. https://doi.org/10.1007/s10021-015-9952-z

Sodhi, N. S., Lee, T. M., Sekercioglu, C. H., Webb, E. L., Prawiradilaga, D. M., Lohman, D. J., Pierce, N. E., Diesmos, A. C., Rao, M., \& Ehrlich, P. R. (2010). Local people value environmental services provided by forested parks. Biodiversity and Conservation, 19, 1175-1188.

TEEB in Policy, (2011). In: ten Brink., P. (Ed.), The Economics of Ecosystems and Biodiversity in National and International Policy Making. Earthscan, London.

Turner, B. L., II., Meyer, W. B., \& Skole, D. L. (1994). Global land-use/land cover change: Towards an integrated study. Ambio, 23, 91-95.

WB \& ESA, (2011). Technical Note on 'Historical assessment of spatial Growth of built-ups in Metropolitan areas of Delhi and mumbai in india and Dhaka in Bangladesh'; detailed statistics and analysis [annex to operational doc] 2011. World Bank and European Space Agency

van der Geest K. et al. (2019). The impacts of climate change on ecosystem services and resulting losses and damages to people and society. In: Mechler R., Bouwer L., Schinko T., Surminski S., LinneroothBayer J. (eds) Loss and Damage from Climate Change. Climate Risk Management, Policy and Governance. Springer, Cham. https://doi.org/10.1007/978-3-319-72026-5_9.

Publisher's Note Springer Nature remains neutral with regard to jurisdictional claims in published maps and institutional affiliations. 